\title{
Manzum Hilyeler Üzerine Bazı Yeni Bilgiler*
}

\author{
A New Analysis of the Hilyes in Poetic Form
}

\author{
Mehtap Erdoğan Taş*
}

\section{Öz}

Hilye, Hz. Muhammed'in fiziksel görünüşünü, güzel ahlakını, karakterini, güzel vasıf ve sıfatlarını, kıyafetini anlatan aynı zamanda diğer peygamberlerin, dört halifenin, aşere-i mübeşşereden diğer sahabelerin, $\mathrm{Hz}$. Hasan ve Hüseyin ile bazı tarikat kurucularının öncelikle fiziksel yapıları olmak üzere onlarla ilgili diğer bazı hususları da konu edinen, genellikle mesnevi nazım şekliyle vegenellikle manzum olarak yazılan, mensur örneklerinin yanı sıra çok az da olsa manzum-mensur olarak da kaleme alınan aynı zamanda levha şeklinde de hazırlanan eserlerin genel adıdır. Türk edebiyatında ilk izlerine 15. yüzyıldan itibaren rastlanmaya başlanan hilye, zaman içerisinde büyük gelişme göstermiş ve varlığını günümüze kadar sürdürmüş edebî bir türdür.

Hz. Peygamber'e duyulan eşi görülmemiş büyük sevgi, onun hilyesini okuyanın ve ezberleyenlerin bu dünyada ve ahirette büyük mükafatlara erişeceği, onu rüyasında göreceği ve birçok felaketten korunacağına dair oluşan inançlar, peygamberin şefaatine vasıl olma isteği, iyi bir eser bırakarak gelecek nesiller tarafindan anılma arzusu, rüyada görülen kimliği belirli ya da belirsiz bir kimsenin hilye yazılması yönündeki isteği, hilye sahasında Hâkânî’nin gösterdiği başarının daha sonraki hilye yazarları üzerinde bıraktığı tesir ve Hz. Peygamber'in resminin yapılmasına İslam inancının izin vermemesi bu türün ortaya çıkmasında ve yaygınlaşmasında rol oynayan önemli etkenlerdir.

Bu makalede tespit edilen 43 manzum hilye metninden hareketle manzum hilyelerin tanımı yapılacak, Hz. Peygamber hilyeleri ile diğer hilyelerin ortaya çıkış ve yazılış nedenleri üzerinde durulacak, bu türün yüzyıllar içindeki gelişimi gözler önüne serilerek türle ilgili bilinen ve sürekli tekrarlananbazı yanlışlara dikkat çekilecektir. Ayrıca literatürde adı geçmeyen yeni hilye metinlerinden ve hilye benzeri bazı manzumelerden bahsedilecektir.

\section{Anahtar Kelimeler}

Hilye, Şemail, Manzum, Edebî tür, Türk edebiyat, Türk-İslam Edebiyatı

\begin{abstract}
Hilye is the general term for works dedicated to the physical appearance, morality, personality, beautiful qualities, and description of the Prophet Muhammad, as well as those of other prophets, the four caliphs, Hasan and Hussain, and certain founders of the Sufi orders. Although primarily written in poetic form, some versions involved a mix of prose and poetry or were presented graphically in the form of panels. Hilye first appeared as early as the 15th century, continued to develop over time, and have endured to the beginning of the 21st century. It is a genre unique to Turkish literature.

The important factors in the emergence and spread of this genre can be identified as follows: The great passion for the Prophet Muhammad; the belief that those who read and memorize his hilye will gain great rewards in this world and in the hereafter, will see him in their dreams, and will be protected from many disasters; the desire to be worthy of the Prophet's intercession; the desire to be remembered by leaving behind a text; the influence of Mehmet Hâkânî's achievement on later writers of hilye; and the fact that Islam does not allow the Prophet to be portrayed by drawing or painting.

* Bu makale, Mehtap Erdoğan tarafindan 2011 yılında Cumhuriyet Üniversitesi Sosyal Bilimler Enstitüsünde tamamlanan "Türk Edebiyatında Manzum Hilyeler" adlı doktora tezinden üretilmiştir.

** Sorumlu Yazar: Mehtap Erdoğan Taş (Prof. Dr.), Sivas Cumhuriyet Üniversitesi, Edebiyat Fakültesi, Çağdaş Türk Lehçeleri ve Edebiyat Bölümü, Sivas, Türkiye. E-posta: merdogan@cumhuriyet.edu.tr ORCID: 0000-0002-5588-0194

Atf: Mehtap Erdogan Tas, “Manzum Hilyeler Üzerine Bazı Yeni Bilgiler.” darulfunun ilahiyat 32, 1 (2021): $293-315$.
\end{abstract}

https://doi.org/10.26650/di.2021.32.1.890487 
In this paper, the poetic hilyes will be discussed based on the 43 examples of the form that have been identified thus far. The reasons for the emergence and writing of hilye for the Prophet will be emphasized, the development of the genre over the centuries will be revealed, and some known and frequently repeated mistakes in the genre will be discussed. Certain new texts not mentioned in the existing scholarship on hilye, and some similar poems, will also be considered.

\section{Keywords}

Hilye, Şemail, In verse, Literary, Turkish literature

\section{Extended Summary}

In its most basic sense, hilye can be defined as a physical and psychological portrait of the Prophet Muhammad. Known by names such as hilye-i şerîf, hilye-i şerîfe, and hilye-i nebevî, it is a literary genre on which many studies have been carried out to date. These works can be literary, in the form of poetry or prose, or graphic, in the form of panels. While the poetic and graphic types have been studied extensively, hilye in prose form still await detailed study.

In Arabic literature, the first hilye and şemail are found in siyer and megazi-books written after the Prophet Muhammad's death. The earliest book of hilye and şemail was that of Imam Tirmizî. Although this book, in which the physical and psychological characteristics of the Prophet Muhammad are explained in detail, has no literary aim, it was nonetheless the main model of writing hilye for Ottoman Turks. Hilye and şemail are not encountered in Iranian literature, thus it can be said that hilye is a literary genre particular to Muslim Turks.

In Turkish literature, the earliest known traces of hilye are from the 15th century, and the tradition of writing them continues today. Şerîfî independently wrote the first hilye in the form of a poem. Hâkânî, on the other hand, produced the finest example of the genre and thus established a model for all hilye written in the following centuries. Cevrî and Neşâtî are also famous names in the genre, comparable to Hâkânî, who influence subsequent hilyes. Those who wrote hilye, except those devoted to the Prophet Muhammad, remembered Cevrî and Neşâtî alongside Hâkânî. This demonstrates that the tradition of writing hilye developed along two different branches: those devoted to the Prophet Muhammad and those that were not.

More recently, Hayreddin Karaman wrote a work titled Gönüllerin Süsü Hanelerin Zineti Hilye, including a 17 part poem at the beginning and two additional poems in the hilye genre. Muhammet Ali Eşmeli, under the pseudonym Seyrî, has produced the last known example of this genre with his work Hilye-i Şerîfe, composed of 1001 couplets in the form of mesnevi verse and employing the "Fe'ilâtün Fe'ilâtün Fe'ilün" metrical pattern.

When evaluating hilyes in terms of content, the key element that determines the type of hilye is the person it addresses. Thus, hilyes can be separated into seven categories: 
hilye of the Prophet Muhammad, hilye of the four caliphs, hilye of prophets, hilye of Aşere-i Mübeşşere, hilye of Hazrat Hasan and Hazrat Hussein, hilye of the four imams, and hilye of sect founders. Hilyes written in the form of mesnevi generally begin with the chapters besmele, hamdele, tevhid, münâcât, na't, medhiye, and sebeb-i te'lîf, proceed to the main subject, the hilye chapters, and end with the hatime chapters. In other hilyes, which are not voluminous and are usually a section or poem in a separate work, the hilye section commences after an introduction to the subject of only a few staves. The physical characteristics of the person under consideration are conveyed superficially in a stave or verse.

In terms of structure, the mesnevi poetic form is used mostly in stand-alone hilyes, whereas kaside poetry is preferred mostly in hilyes that are comparatively brief and often written as a chapter in a separate work.

This study reveals that there are no hilyes by Kastamonulu Nûrî, Azîz Mahmûd Hüdâyî, Cûdî, Niyâzî-i Misrî, Nakşî Mustafa Dede, Hayrullâh Hayrî, Nesîmî Mehmed, nor is there a hilye in poetic form in which Hazrat Hatice is depicted. Hilye in poetic form belonging to Merâmî and 'Îdî from Halep, figures not previously noted in scholarship, are identified. Several other hilye are noted, including those of the Prophet Muhammad in Selamî's Divan, Abdullah Ferdî’s Divan, and İsmâil Sâdık Kemâl Paşa's work Âsâr-ı Kemâl, a hilye of Hacı Bayram-1 Velî in Râzî's Divan, and a hilye of prophets in Vehbî Efendi's mesnevi Manzume-i Nu'mâniyye. It is argued that, although the latter 27 stave hilye is not a separate work, it should be included by scholars as the second verse on the prophets after Neşâtî's Hilye-i Enbiyâ. It is suggested that Muhammet Ali Eşmeli, pseudonym Seyrî, should be regarded as the writer of the last hilye in poetic form, his 2011 work Hilye-i Şerîf, rather than Mustafa Fehmi Gerçeker whose Hilye-i Fahr-i Âlem was printed in 1944. It is stated that the tuyuğ, in which some of the Prophet Muhammad's limbs were praised in Seyyid Nesîmî's Divan and Dede Ömer R̂̂şenî's Divan, should be regarded as "hilye-like poems." Finally, it is noted that certain works other than hilye, such as dictionaries, grammar books, and silsilename (genealogical scrolls), are sometimes called hilye. Thus, not every work labeled as hilye may actually belong to the literary genre of hilye. 


\section{Giriş}

Hilye, Arapça bir isim olup حلى kökünden gelen ve Arapça sözlüklerde süs, bezek, vasıflandırmak, yaradılış, suret, değerli taşlarla ve süslerle yapılııı̧ süs, insanın dış görünüşü anlamlarına gelmektedir. Sözlük anlamına baktığımızda hilyenin süs, zinet, bezek gibi maddi anlamlarının yanı sıra güzel görünüş, güzel karakter gibi manevi anlamlarının da olduğunu görürüz. Ayrıca sözlüklerde hilye, terim anlamıyla da değerlendirilerek "Hz. Peygamber'in mübarek vasıfları ve bu vasıflardan bahseden kitap ve levha" şeklinde de tanımlanmıştır.

Kur'an'da Zînet Kavramı başlıklı bir yüksek lisans tezi hazırlayan İdris Sağır hilye kelimesinin Kuran-ı Kerîm'de nasıl kullanıldığını şöyle açıklamıştır: Bu kelime Kur'an'da h-l-y kökünden türeyen ve düzensiz fiillerden meydana gelen isimlerin genel adıdır. Kur'an'da mecaz anlamda değil, hep gerçek ve somut manada kullanılmıştır. Kelime Kur'an'da 4 ayette fiil, 5 ayette de isim olmak üzere toplam 9 ayette geçmiştir. Iİdris Sağır'ın verdiği bilgiye göre bu ayetlerde geçen hilye kelimesinin anlamları şu şekildedir: Cennetliklerin takındıkları gümüş bilezik, iman edip salih amel işleyenlerin cennette takacakları altın bilezikler, iman edip salih amel işleyenlerin cennette altın bilezik ve incilerle bezenmeleri, zinet, denizden çıkarılan inci, buzağı heykeli yapılan zinet takımı, süs ve süs eşyası. ${ }^{2}$

İdris Sağır, güzelleşmek ve süslenmek gibi ortak bir anlamda buluşan ziynet ve hilye kelimelerinin Kuran-ı Kerîm'de olumlu ya da olumsuz anlamda kullanılmaları arasındaki farkı, hilye kelimesinin fiil anlamının salt olarak ziynetin yalnızca süslenmek ve bezenmek yönünü dolayısıyla maddi yönünü şamil olduğunu, ziynette var olan gerçekte süslü ya da çekici olmadığı hâlde nefsin ve şeytanın telkinleriyle cazip görünmesi anlamının hilyede bulunmadığını, hilye ayetlerinin genel olarak iman etmekle ilgili olmalarından dolayı bu ayetlerde Mekkî ayetlerin karakteristiğinin hakim olduğu sonucuna varılabileceğini söyleyerek açıklar. ${ }^{3}$ Görüldüğü üzere hilye, Kuran-ı Kerîm'de yalnızca kelime anlamıyla ve olumsuz anlamlar içermeyen ifadelerde kullanılmıştır.

Türk edebiyatında hilye-i şerîf, hilye-i şerîfe, hilye-i nebevî gibi isimlerle anılanhilye, bugüne kadar üzerinde pek çok araştırmanın yapıldığı edebî bir türdür. Bugüne kadar defalarca hilyenin tanımı yapılmış ve her geçen gün bu tanıma yeni bir şeyler eklenmiştir. Önceleri sözlüklerde "Hz. Peygamber'in mübarek vasıfları" şeklinde değerlendirilen ve zamanla bu tanımına yeni bilgilerin de eklendiği hilyeyi

1 Sağır, İdris. Kur'an'da Zinet Kavramı, (Basılmamış Yüksek Lisans Tezi), Kahramanmaraş: Kahramanmaraş Sütçü İmamÜniversitesi Sosyal Bilimler Enstitüsü, 2009, 17.

2 Sağır, İdris. age. 17-18.

3 Sağır, İdris. age.18. 
yeniden tanımlamak, mevcut tanımları genişletmek ve genellemelere ulaşmak için bugün elimizde çok daha fazla malzeme bulunmaktadır.

Hilyelerde asıl olarak Hz. Peygamber'in fiziksel tasvirinin yapılması, edebî bir tür olarak hilye tanımlarında bazen onun bazen güzel ahlakına, özellikle de kıyafetine yer verilmemesine neden olmuştur. Ancak başta Hâkânî olmak üzere Nahîfî, Mehmed Necîb, Mustafa Fevzî, Âşık Kadrî gibi hilye sahasında adından bahsedilmeye değer isimler, eserlerinde dikkate çekecek şekilde Hz. Peygamber'in kıyafetinden de bahsetmişlerdir. Bu tür hilyelerde Hz. Peygamber'in fiziksel görüntüsü kıyafetle tamamlanmış, güzel ahlakının verilmesiyle de derinlik ve canlılık kazanmıştır. Bu nedenle hilye tanımları içerisine fiziksel tasvirin yanı sıra güzel ahlakınve kıyafetin de eklenmesi gerektiğini düşünüyoruz.Elimizdeki malzemeyi göz önünde bulundurarak şimdi hilyeyi şu şekilde tanımlayabiliriz:

Hz. Muhammed'in fiziksel görünüşünü, güzel ahlakını, karakterini, güzel vasıf ve sıfatlarını, kıyafetini anlatan aynı zamanda diğer peygamberlerin, dört halifenin, aşere-i mübeşşereden diğer sahabelerin, Hz. Hasan ve Hüseyin ile bazı tarikat kurucularının öncelikle fiziksel yapıları olmak üzere onlarla ilgili diğer bazı hususları da konu edinen ve genellikle mesnevi nazım şekliyle manzum ya da mensur olarak yazılan eserlerin genel adıdır. Ancak burada şunu da belirtmeliyiz ki hilyelerin başkaları için de yazılmış olması bu edebî türün asıl Hz. Peygamber ile ilgili eserler olma özelliğini kaybettirmemiştir. Hilye denilince her zaman akla ilk gelen Hz. Muhammed hilyeleri olmuştur.

\section{Hilye Türü Nasıl Ortaya Çıktı ve Nasıl Gelişti?}

Konusu doğrudan doğruya Hz. Peygamber'i anlatmak olan ve resululllah efendimizin bir tek yönünü kendisine konu edinen ilim dalları vardır. Bunlar hadis, siyer, megazi, şemail ve delaildir. ${ }^{4}$ Bunlardan bizim konumuzla yakından ilgili olan şemail, Hz. Peygamber'in beşerî yönünü kendine konu edinen ilim dalı olarak tanımlanabilir. Şemailler konu itibariyle Hz. Peygamber'in hem suretini hem de siretini verir. Yani bu tür eserlerde Hz. Peygamber'in hem fiziksel özellikleri hem de giyinişi, yaşantısı, ibadetleri, eşyaları, davranışları, ahlakı, huyları, iç dünyası, mirası, vefatı gibi ona ait pek çok husus yer alır. İşte edebî bir tür olarak hilyeler de aslında şemaillerden doğmuştur. Şemailler içerisinde bir bölüm olarak ele alınan Hz. Peygamber'in dış görünüşü hilyelerin ana konusunu oluşturmuş ve daha sonra hilye ayrı bir edebiyat türü hâlinde gelişim göstermiş ve zamanla o da kendi içerisinde dört halife hilyeleri, peygamberler hilyesi, aşere-i mübeşşere hilyeleri, Hz. Hasan ve Hz. Hüseyin hilyeleri gibi değişik kollara ayrılmıştır.

4 Yardım, Ali. Peygamberimizin Şemâili, İstanbul: Damla Yayınevi, 2011.40. 
Şemailden ayrılarak ayrı bir tür hâlini almış olan hilyelerin yazılma sebepleri, elimizdeki hilyelerden hareketle "Hz. Peygamber Hilyelerinin Yazılma Sebepleri" ile "Diğer Hilyelerin Yazılma Sebepleri" adlı iki ana başlık altında değerlendirilebilir.

\section{A. Hz. Muhammed Hilyelerinin Yazılma Sebepleri}

Hilyelerin ortaya çıkma nedenleri, bazı hilyelerde Hz. Ali'den, Şeyh Sadrüddîn'den rivayetlerle ve Hârûnü'r-Reşîd' in rüyasından hareketle verilmektedir. Hilye türünün ortaya çıkma sebeplerini sıralamaya geçmeden önce hilyelerden hareketle bu rivayetlerden ve Hz. Muhammed'i rüyada görme konusundan bahsetmek istiyoruz.

Hâkânî'nin, hilyesinde naklettiği, daha sonra başka hilyelerde de zikredilen ve hilyelerin ortaya çıkma nedenlerinin çoğunun toplu olarak verildiği Hz. Ali'nin rivayeti şöyledir:Ali b. Ebî Tâlib (ra)'tan: "Resulullah (sav) şöyle buyurmuştur: 'Benden sonra hilyemi gören beni görmüş gibidir. Kim bana olan sevgi ve özlem ile hilyeme bakarsa Allah ona cehennemi haram k1lar. O kişi kabir fitnesinden emin olur, mahşer günü çıplak olarak haşredilmez.' Resulullah doğru söylemiştir."

Hz. Peygamber kendisinden sonra hilyesini gören kişinin, kendisini görmüş gibi olacağını, ona özlem duyarak bakan kişiye Allah'ın cehennemi haram edeceğini ve onu kabir fitnesinden emin kılacağını, kıyamet gününde çıplak olarak haşretmeyeceğini söylemiştir. Hâkânî bu rivayetin bizzat Hz. Ali'den nakl edildiğini söylemektedir.

Diğer bir rivayet ise Şeyh Sadrüddîn'e aittir. Hâkânî, Şeyh Sadrüddîn'in rivayetini şöyle nakleder5: "Kim hilyeyi yazıp arada sırada ona baksa belalardan ve vesveseden uzak kalır. O kişiye hac ve köle azadı sevabı verilir, hastalıklardan korunur, dünyada ve ahirette azap görmez. Hilyenin bulunduğu evde fakirlik ve dert bulunmaz. Şeytan da o eve giremez." Yine bu rivayete de hilyelerin çoğunda yer verilmiştir.

Yukarıda verilen iki rivayet Abbasi halifesi Hârûnü'r-Reşîd'in gördüğü bir rüya ile desteklenir. Bu rüyayı Hâkânî şöyle anlatır6: Bir fakir Hârûnü'r-Reşîd'e hilye hediye eder. Buna çok sevinen Hârûnü'r-Reşîd o fakire pek çok ihsanda bulunur ve o gece rüyasında Hz. Peygamber'i görür. Hz. Peygamber ona "Allah bana müjdeler verdi ve dedi ki: "Kim senin hilyeni gördüğü için sevinirse kıyamet günü cehennem ateşi onun vücuduna haram olur. O kişi dünyada ve ahirette azap görmez, yüzümü görmeye layık olur.” der.

5 bk. Erdoğan, Mehtap. Türk Edebiyatında Manzum Hilyeler, İstanbul: Kitabevi Yayınları, 2013, 124-215.

6 bk. Erdoğan, Mehtap.age., İstanbul: Kitabevi Yayınları, 124. 
Hilyelerin yazılma nedenlerinin çoğunun toplu olarak verildiği yukardaki rivayetlere ve hilyelerin özellikle sebeb-i telif ve hatime bölümlerinden edindiğimiz bilgilere göre ve bunlara ilave edilen ilk iki maddeyle hilyelerin yazılma nedenlerini şu şekilde sıralayabiliriz?:

1. Hz. Peygamber Sevgisi

2. İslamiyette Resmin Yasak Olmas1

3. Hz. Peygamber'in Vasiyeti

4. Hz. Peygamber'i Rüyada Görme Arzusu

5. Hz. Peygamber'i Rüyada Görüp Hilye Yazmak

6. Hilyelerin Koruyucu Özelliği

7. Hz. Peygamber'in Şefaatine Vasıl Olma İsteği

8. Hâkânî’nin Etkisi

a. Hz. Peygamber Hilyelerinin Yazılmasına Etkisi

b. Diğer Hilyelerin Ortaya Çıkmasına Etkisi

9. İstek Üzerine Hilye Yazma

10. İyi Bir Eser Bırakarak Gelecek Nesiller Tarafindan Anılma Arzusu

11. Mecliste Yüksek Sesle Okunması İçin Hilye Yazılması

\section{B. Diğer Hilyelerinin Yazılma Sebepleri}

Hz. Peygamber hilyesi dışında kalan diğer hilyelerin yazılma sebeplerini ise şöyle sıralayabiliriz:

1. Hâkânî’nin Etkisi

2. Cevrî’nin ve Neşâtî’nin Etkisi

3. İstek Üzerine Hilye Yazma

4. İyi Bir Eser Bırakarak Gelecek Nesiller Tarafından Anılma Arzusu

5. Diğer Nedenler

Buraya kadar söylediklerimizi özetleyecek olursak Hâkânî ile birlikte Cevrî’nin ve Neşâtî’nin şairler üzerinde bıraktığı tesir, Hz. Peygamber hilyelerinin yazılmasının başlıca nedenidir. Bu üç isim başarılarıyla şairler üzerinde büyük bir etki bırakmış, bu başarı aynı zamanda hilye yazmaya niyet eden şairlere âdeta onların yazdıkları konularda hilye yazma yolunu kapatmış, bu durum onları farklı konularda hilye

7 Hz. Peygamber hilyelerinin ortaya çıkış nedenleri için ayrıca bk. Güngör, Zülfikar. "Türk Edebiyatında Hilye-i Nebevî Türünün Doğuşu Gelişimi ve Sebepleri”, İlmî ve Akademik Araştırma DergisiTasavvuf, S. 10 (2003): 185-199. 
yazmaya yöneltmiş ve sonuçta nazire olmasa da bir zeyl geleneğinin oluşmasına zemin hazırlamıştır. Bunun yanı sıra iyi bir eser bırakarak ileride hayırla anılma arzusu ve devrin padişahının belirlediği bir konuda hilye yazılmasını istemesi bazı hilyelerin ortaya çıkmasına vesile olmuştur. Peygamberin şefaatini kazanma, hilyelerde ele alınan kişilerin hürmetine Allah’tan af dileme ise bu tür hilyelerin kısmen yazılma nedeni olmakla birlikte daha çok sonucu olarak görünmektedir.

\section{Türk Edebiyatında Hilye}

Arap edebiyatında hilye ve şemâillere Hz.Peygamberin vefatından sonra yazılan siyer ve megazi gibi kitaplarda da yer yer metinler hâlinde rastlanırsa da bunlar bir şemâil ve hilye tekniği ile yazılmamışlardır. Urve b. Zübeyr, Veheb b. Hind, Ebu Muhammed Yahya b. Saîdü'l- Emevî gibi ilk siyer tarihçilerinin eserlerinde Hz. Peygamber'in gazaları vesile edilerek yazılan onun vasfi, seciye ve meziyetlerini tasvir eden şemâilimsi kısımlar vardır (Türk Dili ve Edebiyatı Ansiklopedisi 1981: 237). İlk şemâil ve hilye kitabı İmam Tirmizî’ye aittir. Hz. Peygamber'in maddi ve manevi özellikleri ayrıntılı bir şekilde anlatılmış olmasına rağmen edebî bir gaye ile yazılmadığı için eser, hilye vadisinde bir çığır açamamıştır. Ancak bu türün ilk örneği olması ve Osmanlı Türklerine hilyecilik konusunda temel kaynak olması bakımından önemli bir eserdir. İmam Beyhakî’nin Delâilü'n-Nübüvve'si, Hâfız-1 Isfahanî'nin Tarih-i Isfahan'1, Cemâleddin Hâfiz Abdurrahman'ın Vefầ fi Fezâil-i Mustafâ'sı ve Kadı İyaz'ın Şifâ-1 Şerîf adlı kitapları Arap edebiyatının başlıca şemâil ve hilye kitaplarıdır. Türk edebiyatında birçok hilye yazılmasına rağmen İran edebiyatında şemâil ve hilye türüne hemen hemen hiçbir yerde rastlanamamıştır (Türk Dili ve Edebiyatı Ansiklopedisi 1981:237). Bunu göz önünde bulundurarak hilyenin Müslüman Türklere ait bir çeşit millî edebiyat türü olduğu söylenebilir.

Türk edebiyatında ilk izlerine 15. yüzyıldan itibaren rastlanmaya başlanan hilye, zaman içerisinde büyük gelişme göstermiş ve varlığını günümüze kadar sürdürmüştür. Tam anlamıyla hilye olarak kabul edilemese bile 15. yüzyılda Seyyid Nesîmî ile Dede Ömer Rûşenî, tuyuğ şeklinde yazdıkları hilye benzeri manzumelerle hilye türünün müstakil olmayan ilk örneklerini vermişlerdir. Müstakil bir manzume olmayan ancak tam olarak hilye özelliği gösteren metnin ilk örneği ise 15. yüzyılda Yazıcıoğlu Mehmed'in Muhammediye adlı eserinde görülmektedir. Bu dönemin hilye türü için bir hazırlık dönemi olduğunu söyleyebiliriz.

16. yüzyıl hilye türünün hem ilk müstakil örneğine hem de en güzel örneğine sahip olması bakımından bu tür için oldukça önemli bir yüzyıldır. Bu yüzyılda Şerîfi, müstakil olan ilk manzum hilyeyi yazmış, Hâkânî ise türünün en güzel örneğini vererek daha sonraki yüzyıllarda yazılacak olan hilyelerin temelini oluşturmuştur. 
17. yüzyıl gerek sayı bakımından gerek çeşitlilik bakımından gerekse eserlerin niteliği bakımından en zengin yüzyıl olarak görünmektedir. Mehmed Es‘ad Efendi yazdığı dört halife hilyesiyle Hz. Peygamber hilyesi dışındaki hilyenin ilk örneğini vermiş ve böylece 17. yüzyılın hemen başlarında hilye konuları genişlemeye başlamıştır. Dört halife hilyesiyle Cevrî, peygamberlerhilyesiyle Neşâtî, aşere-i mübeşşere hilyesiyle Güftî, Mevlânâ hilyesiyle Lütfî Çelebi bu yüzyılda hilye türünün içeriğini değiştiren ve geliştiren isimlerdir. Hz. Peygamber hilyesinde bu yüzyılın öne çıkan ismi ise en hacimli ve dolayısıyla en kapsamlı hilye olma özelliğini taşıyan Hilyetü'l-Envâr ile Nahîfî olmuştur. Edebiyatımızda müstakil iki hilye sahibi tek isim olan Mehmed Es'ad Efendi ise aynı zamanda ilk dört halife hilyesinin sahibi olmasına rağmen şairler arasında da günümüzde de hilye sahasında Cevrî kadar şöhret bulamamış bir isimdir.

18. yüzyılda Hz. Peygamber hilyelerinin sayısında bir azalma görülürken diğer hilyelerin sayısında ve çeşitliliğinde bir artış görülür. Ârif Süleymân ile Hâkim Seyyid Mehmed Efendi, Hz. Peygamber hilyesinde yüzyılın iki önemli ismidir. İlk örneğine 17. yüzyılda rastlanılan aşere-i mübeşşere hilyesinin bir örneğini de bu yüzyılda $\mathrm{Na}$ ‘î verir. Her ne kadar aşere-i mübeşşere hilyesi denilince akla ilk gelen isim Güftî olsa da tam anlamıyla aşere-i mübeşşere hilyesinin bizce ilk sahibi Na 'tî' dir; çünkü $\mathrm{Na}$ 'tî’nin hilyesinde aşere-i mübeşşerenin fiziksel özellikleri verilmesine rağmen Güftî’nin hilyesinde aşere-i mübeşşerenin hilyesi değil, hayatları ele alınmıştır. Ancak Güftî’nin hilyesi Hz. Hasan ile Hz. Hüseyin'in hilyesini veren ilk manzume olması ve dört halife hilyesini de vermesi bakımından önemlidir. Aşere-i mübeşerre hilyesinde yüzyılın diğer önemli bir ismi de Şâkir Mehmed olmuştur. Bu yüzyılda Safhî tarafindan türünün tek örneği olan dört imam hilyesi yazılmış, Salâhî-i Uşşâkî tarafindan Hz. Hasan ve Hz. Hüseyin hilyesinin ilk müstakil örneği verilmiştir. Bu yüzyılda Neccâr-zâde Rızâ, Hâce Bahâeddîn; Râzî ise Hacı Bayram-ı Veli hilyesini yazarak tarikat büyükleri için yazılan hilyelere bir çeşitlilik kazandırmışlardır.

19. yüzyıl hilye türünün ortaya çıkmaya ve gelişmeye başladığı dönemler bir tarafa bırakılırsa bu türün en zayıf dönemi olarak kabul edilebilir. Bu yüzyılda hilye türü en durgun dönemini yaşamıştır. Yüzyılın hilyeleri sayı bakımından yetersiz olduğu gibi çeşitlilik bakımından da bir zenginlik göstermez. Hatta bu yüzyılın tek müstakil hilyesi Mehmed Necîb'e aittir. Selâmî ve Abdullah Ferdî divanlarında Hz. Peygamber hilyeleri vardır. İsmail Sadık Kemal Paşa'nın Âsâr-ı Kemâl adlı eserinde yinebir Hz. Peygamber hilyesi bulunur. Hanyalı Nûrî ise divanında Hz. Hasan ve Hz. Hüseyin hilyesine yer vermiştir.

20. yüzyılda önceki yüzyılın aksine hilye türünde bir canlılık görülür. Mustafa Fevzî, Âşık Kadrî ve Mustafa Fehmi Gerçeker bu tür için oldukça hacimli 
sayılabilecek eserlerinde Hz. Peygamber'in fiziksel özelliklerini detaylı bir şekilde ele alırlar. Bursalı Rıza Dede ile Tâhirü'l-Mevlevî, Mevlânâ hilyeleriyle; Rıza ise Şazelitarikatının kurucusu için yazdığı hilye ile yüzyılınhilye şairleri arasında yerlerini almışlardır.Hûdek-zâde Nu'mân Vehbî Efendi ise Manzûme-iNu 'mâniyye adlı eserinde 27 beyit içerisinde peygamberlerhilyesine yer vererek Neşâtî' den sonrapeygamberler hilyesi yazan ikinci isim olmuştur.Prof. Dr. Hayreddin Karaman 1992 yılında bentlerhâlinde ve 11'li hece ölçüsüyle yazdığı manzumesiylebu türü 21. yüzyılın eşiğine taşımıştır.

Hayreddin Karaman,2008 yılında hece ölçüsüyle Hakanî’nin hilyesininmanzum tercümesini yapmıştır. Seyrî (M. Ali Eşmeli)ise aruz vezniyle yazıp 2009 yılında tamamladığıHilye-i Şerîf adlı eseriyle hilye yazma geleneğinigünümüze kadar taşımıştır. Hz. Peygamber'eduyulan eşsiz ve derin sevgi devam ettiği sürecebu türün yeni örnekleri verilmeye devam edecekgibi görünmektedir.

Sonuç olarak Türk edebiyatında hilye türününilk örneklerine 15. yüzyılda rastlandığını, 16.yüzyılda ilk müstakil örneklerinin verildiğini, 17.yüzyıldan itibaren Hz. Peygamber hilyeleri dışındabaşka hilyelerin de artık kaleme alınmaya başladığınıve böylece türün sınırlarının genişlemeyebaşladığını, 18 . yüzyılda da bu gelişmenin yaşanmayadevam ettiğini, 19. yüzyılda türde bir duraklamanınyaşanmasına rağmen 20. yüzyılda tekrarbir canlanmanın görüldüğünü, 21. yüzyılda kalemealınan hilyeler vasıtasıyla hilye yazma geleneğiningünümüze kadar devam ettiğini söyleyebiliriz.

\section{Hilyelerin Kaynakları}

Hilyelerin ve şemaillerin kaynağını daha çok kütüb-i sitte adıyla bilinen, hadislerin büyük bir kısmını ve genellikle güvenilir olanlarını ihtiva eden altı büyük hadis kitabı ve diğer hadis kitaplarındaki hadis-i şerifler oluşturmaktadır. Bazı hilyelerde özellikle Buhârî, Müslim, Tirmizî ve İbni Mâce'nin adları sıklıkla anılır. Bunun yanı sıra Gazalî'nin İhyâ-i Ulûm'u da hilyelere kaynaklık etmiştir.

Hz. Peygamber'in hilyesiyle ilgili hadisleri rivayet edenler arasında Hz. Ali, Hz. Aişe, Mu'aykab, Ebû Hureyre, Enes b. Mâlik, İbni Âzib, Mâlik, Ebî Hâle, Hakîm b. Hazzâm, Câbir, Ümm-i Ma ‘bed, İbni Abbâs, Bû Huceyf, Harîm, Bû Tufeyl, İbni Affân, Abd-ı Menâf, Ebû Cahîf, İbni Hâlid ve Semmâk yer almaktadır. Özellikle Hâkânî’nin, Nahîfî'nin, Mehmed Es'ad'ın, Necîb'in ve Âşık Kadrî’nin hilyeleri bu isimlerin rivayetleri etrafında oluşturulmuştur. Bu rivayetler bazı hilyelerde ele alınan konuya göre öncelikle bir başlık olarak verilmiş daha sonra bu rivayete uygun olarak o bölüm yazılmıştır. 


\section{Nazire ve Zeyl Kavramları Etrafinda Manzum Hilyeler}

Hâkânî’nin eserinin çok beğenilmesi Hz. Peygamber hilyelerinin gelişimine, onun eserine nazire yazılamayacağı düşüncesi de farklı alanlarda hilye yazılmasına katkı sağlamıştır. Bazı şairler eserlerini Hâkânî’ye nazire olarak kaleme aldığını açıkça belirtirken bazıları da bunun mümkün olamayacağını düşündükleri için farklı bir alanda hilye yazmaya karar verdiklerini söylemişlerdir.

Hilyesini tamamladıktan 42 yıl sonra, Hâkânî' den bahseden ilk isim Cevrî olmuştur. Cevrî'den sonra hemen hemen bütün hilye şairleri Hâkânî’nin adını anmadan geçememiş, bu durum zamanla âdeta bir gelenek hâlini almıştır.

Hz. Peygamber hilyesi yazan şairler içinde Hakânî'den ilk bahseden isim ise hilyesini Hâkânî'nin eserinden 90 yıl sonra kaleme almış olan Nahîfî'dir. Bunu sırasıyla Hayrullah Hayrî, Ârif Süleyman, Mehmed Necîb, Mustafa Fevzî b. Nu'mân, İsmail Sadık Kemal Paşa, Âşık Kadrî ve Mustafa Fehmi Gerçeker takip eder.

Cevrî ile Neşâtî de hilye sahasında en az Hâkânî kadar meşhur olan ve diğer hilyelere yön veren isimlerdir. Hz. Peygamber hilyesi dışında hilye yazanlar Hâkânî ile birlikte Cevrî̀yi ve Neşâtî'yi de anmışlardır. Bu da gösteriyor ki hilye yazma geleneği zaman içerisinde Hz. Peygamber hilyesi üzerinden ve diğer hilyeler üzerinden iki ayrı koldan gelişmeye devam etmiştir. Aşağıda yaptığımız sıralamanın öne çıkan bu üç ismin hilye şairleri üzerindeki etkilerini daha net bir şekilde göstereceğini düşünüyoruz. Aşağıdaki sıralama doğrudan birbirinin isminden bahseden şairlerden hareketle oluşturulmuştur. Sıralamaya alınmayan şairlerin çoğunda da yazdıkları hilyenin çeşidine göre bu üç ismin etkisi hissedilmektedir.

\section{Kol: Hz. Peygamber Hilyeleri}

\section{Hâkânî aracılığıyla:}

- Nahîfî

- Müellifi Bilinmeyen Hilye

- Ârif Süleymân

- Mehmed Necîb

- Mustafa Fevzî b. Nu'mân

- İsmâil Sâdık Kemâl Paşa

- Âşık Kadrî

- Mustafa Fehmi Gerçeker 


\section{Kol: Diğer Hilyeler}

\section{a. Hâkânî -Cevrî aracılığıyla:}

- Güftî (Aşere-i Mübeşşere Hilyesi)

- Na'tî (Aşere-i Mübeşşere Hilyesi)

- Şâkîr Mehmed (Așere-i Mübeşşere Hilyesi)

- Hanyalı Nûrî (Hz. Hasan ve Hz. Hüseyin Hilyesi)

\section{b. Hâkânî -Cevrî -Neşâtî aracıllğıyla:}

- Lütfî Çelebî (Mevlana Hilyesi)

- Safhî (Dört İmam Hilyesi)

- Salâhî (Hz. Hasan ve Hz. Hüseyin Hilyesi)

Hâkânî’nin eserini beğenip ona benzer bir eser vücuda getirme arzusu hilye sahasında nazire geleneğini, Hâkânî’nin taklit edilemeyeceği düşüncesi ile Cevrî ile Neşâtî’nin hilyelerini farklı konularda yazmış olmalarının ve bu iki ismin eserini çok beğenen diğer şairlerin zamanla birbirlerinin eksik bıraktıklarını düşündükleri konulara yönelmelerinin ise zeyl geleneğini başlattığını söyleyebiliriz. ${ }^{8}$

Buraya kadar söylediklerimizi özetleyecek olursak Hâkânî’nin hilyesi, şairleri biri nazire diğeri zeyl olmak üzere iki ayrı yönde etkilemiștir. Şairlerin bir kısmı Hâkânî’ye nazire yazarken bir kısmı da farklı bir alana yönelerek zeyl geleneğini başlatmıştır.

\section{Manzum Hilyelerde Tasvir Yöntemleri}

Şimdiye kadar incelediğimiz bütün hilyelerden hareketle şunu söyleyebiliriz ki bir hilyede ele alınan kişinin fiziksel portresini çizmede iki yöntem kullanılmıştır. Bunlardan birincisi bazı kaynaklardan hareketle gerçeğe dayalı olarak yapılan tasvirlerdir. Bu yolla, hilyede söz konusu edilen kişinin boyunun uzunluğu, kilosu, vücut yapıs1, yüzünün görüntüsü gibi fiziksel özelliklerinin göz önünde net bir şekilde canlandırılması sağlanır. İkinci yöntem ise tasvir edilen kişinin daha çok fiziksel görünüşünün övgüsünü yapmada kullanılır ki hilyelere edebî bir değer ve beyit sayısı itibariyle hacim kazandıran da budur. Özellikle hacimli hilyelerde ikinci

8 Hanyalı Nûrî’nin bu konudaki değerlendirmesi şöyledir: Ba'de-zîn Cevri-i pâkîze-sühan/ Na't-1 ashâbı görüp müstahsen/Dördünün na'tını tafsîl itdi/Hilye-i hazreti tezyîl itdi/Eyledi ol dahi sehv ü nisyân/Kaldı tezyîli anın da noksân/Yazmamış ol dahi şehzâdeleri/Ol iki 'ar'ar-1 âzâdeleri/Hamdü-lillah bana irdi nevbet/Vireyim hâmeme ben de ruhsat/Gerçi haddim degil ey dil ki idem/Medh-i sıbteyn-i şeh-i taht-1 harem/Lîk gayret ile tekmîl itdim/Nüsha-i Cevri'yi tezyîl itdim/İki şâh-zâde-i 'âlî-şâna/Başladım na'tına küstâhâne. bk. Erdoğan, Mehtap,age., 744. Görüldüğü gibi Hanyalı Nûrî burada hem Cevrî’nin hilyesini Hâkânî’nin hilyesinin zeyli hem de kendi hilyesini Cevrî'nin hilyesinin zeyli olarak değerlendirmektedir. 
yol ağırlıklı olmak üzere her iki yol da kullanılmıştır. Bu tür hilyelerde birinci yolla ortaya konulan tasvirin ayrıntıları, ikinci yolla belirginleştirilir ve renklendirilir.

Buraya kadar söylediklerimizi biraz daha netleştirmek için Hz. Peygamber'in kaşlarının anlatıldığı bölümlerden her iki tasvir yöntemi için birer örnek vermek istiyoruz.

Gerçeğe dayalı tasvir: "1. Kaşları uzun ve inceydi. 2. İki kaşının arası açıktı."

Edebî (hayalî) tasvir: "1. Kaşları yay gibiydi, hilal gibiydi. İkbal hümasının bükülmüş kanadı bile onun kaşının eğriliğine benzeyemezdi. Kaşının o kavisli yeri yani köşesi güzellik camisinin mihrabıydı. 2. İki kaşının arası saf ve berraktı. Saf bir gümüş gibiydi."

Yukarıdaki örnekte görüldüğü gibi gerçeğe dayalı tasvirde Hz. Peygamber'in kaşlarının şeklinden bahsedilmiş ve kaşlarının arasının açık olduğu yani iki kaşı arasında kıl bulunmadığ 1 ifade edilmiş, edebî tasvirde ise ortaya konulan bu husus değişik benzetmelerle renklendirilmiştir.

Hilyelerin çoğunda her iki yöntem de genel olarak kullanılmıştır. Ancak bazılarında iki yöntemden biri daha öne çıkmıştır. Örneğin, Bosnalı Mustafa 135 beyitlik hilyesinde daha çok gerçeğe dayalı tasvir yöntemini tercih etmiştir. Böyle olunca da her uzva bir ya da birkaç beyit ancak ayrılabilmiş, hızla bir konudan diğerine geçmek zorunda kalmıştır.SeyyidNesîmî Divânı ile Dede Ömer Rûşen̂̂ Divanı'nda yer alan bazı tuyuğlarda ise Hz. Peygamber'in uzuvları sadece edebî tasvirle anlatılmıştır.

Kaynaklara ve gerçeğe dayalı tasvirler olmadığında ele alınan kişinin görüntüsü olması gerektiği şekilde verilemez. Ortaya bulanık bir görüntü çıkar. Çeşitli benzetmelerden yararlanılarak yapılan tasvire başvurulmadığında ise ifadeler kurulaşır, anlatım etkileyicilikten uzaklaşır, okuyucuya düşünme ve hayal kurma fırsatı kalmaz. Bu nedenle bir hilyede her iki yöntemin orantılı bir şekilde bir arada kullanılması ele alınan kişinin portresinin hem daha canlı ve gerçekçi hem de daha edebî ve etkileyici bir şekilde ortaya konulmasını sağlamaktadır.

\section{Manzum Hilyelerin Muhteva Özellikleri}

Hilyelerin muhteva özelliklerini değerlendirirken konuya iki açıdan yaklaşabiliriz. Bunlardan ilki hilyenin çeşidi diğeri ise hilye içerisinde yer alan bölümlerdir.

Hilyenin çeşidini belirleyen unsur o hilyede ele alınan kişidir. Buna göre elimizdeki 43 hilyeyi Hz. Muhammed Hilyeleri, Dört Halife Hilyeleri, Peygamberler 
Hilyesi, Aşere-i Mübeşşere Hilyeleri, Hz. Hasan ve Hz. Hüseyin Hilyeleri, Dört İmam Hilyesi ile Tarikat Kurucularının Hilyeleri olmak üzere yedi ana başlık altında toplayabiliriz.

Mesnevi şeklinde yazılan bu hilyeler genellikle besmele, hamdele, tevhid, münâcât, na't, medhiye ve sebeb-i te'lîf bölümleriyle başlayıp ana konuyla yani hilye bölümüyle devam eder. Bu bölüm de genellikle üç kısım hâlindedir. Öncelikle Hz. Peygamber'in hilyesinin yazılması yönündeki vasiyetinden bahsedilir, hilyelerin koruyucu özellikleri anlatılır ve ele alınan kişinin fiziksel özellikleri genellikle ayrı ayrı başlıklar altında sıralanır. Eser hatime bölümü ile son bulur. Ancak bazı hilyelerde edebiyatımızda ayrı türler olarak da yazılabilen miraciye ve hicret-nâme gibi türlere de yer verildiği görülür. Örneğin, Nüvâzî’nin ve ‘'̂̂î’nin hilyelerinde miraciye, Mehmed Es'ad Efendi'nin dört halife hilyesinde Hz. Ebubekir'in anlatıldığı bölümde hicret-nâme bulunmaktadır.

Hacimli olmayan ve daha çok müstakil bir eser içerisinde bir bölüm ya da ayrı bir manzume olarak tertip edilen hilyelerde ise birkaç beyitle konuya giriş yapıldıktan sonra hemen hilye bölümüne geçilir ve ele alınan kişinin fiziksel özellikleri birer beyit ya da mısrada yüzeysel olarak verilerek konu tek başlık altında incelenir.

\section{Manzum Hilyelerin Şekil Özellikleri}

Hilyeler çoğunlukla müstakil olarak kaleme alınmış hacimli eserlerdir. Bu nedenle hilyelere hakim olan ana nazım şekli de mesnevidir. Bunun yanı sıra mesnevi nazım şekliyle yazılmış olmakla birlikte bazıları içerisinde farklı nazım şekilleriyle yazılmış bölümler de bulundurmaktadır. Örneğin, Şerîfî’nin hilyesinde kaside, Mehmed Es 'ad'ın hilyesinde gazel, Na 'tî'nin hilyesinde rubai nazım şekliyle yazılmış bölümler vardır. Ayrıca müstakil olmayıp bazı eserlerin içerisinde küçük bir manzume olarak tertip edilen hilyelerle müstakil olup hacimli olmayan hilyelerin farklı nazım şekilleriyle de yazıldığı görülmektedir. Örneğin, müstakil bir manzume olan Hızrî’nin hilyesinin ana bölümü dörtlükler hâlinde yazılmıştır. Geri kalan kısım ise kaside şeklindedir. Aslında Şerîfî’ye ait olduğu hâlde Kastamonulu Nûrî adına kayıtlı bir hilyenin sonunda bulunan Merâmî adlı bir şaire ait altı beyitlik küçük bir hilye ise kıt'a nazım şekliyle yazılmıştır. Birer Hz. Peygamber hilyesi olan Selâmî, Abdullah Ferdî ve İsmâil Sâdık Kemâl Paşa'ya ait müstakil olmayan hilyelerde ise daha çok kaside tercih edilmiştir. Ayrıca Seyyid Nesîmî Divanı ile Dede Ömer Ruşenî Divanı'nda tuyuğ nazım şekliyle yazılmış kısmen hilye özelliği gösteren bölümler vardır.

Vezin konusuna gelince Hz. Peygamber hilyeleri ile diğer bütün hilyelerde aruz vezni kullanılmıştır. Yalnızca 1945 yılında vefat etmiş olan halk şairi Âşık Kadrî 
hilyesini aruz ve hece ölçüsünü birlikte kullanarak tertip etmiştir. Hece veznini kullandığı kısımlar 7, 10, 11 ve 15'li hece ölçüsüyle yazılmıştır.

Beyit sayısı açısından baktığımızda elimizdeki 43 hilyenin toplam beyit sayısı 19193'dir. Beyit sayısı en az olan hilye 6 beyitle Merâmî'ye aittir. Beyit sayısı en fazla olan hilye ise 4071 beyitle Nahîfî'nin hilyesidir. 19193 beytin 15535 beyti Hz. Peygamber hilyesi olup geri kalan 3658 beyit diğer hilyelere aittir. $\mathrm{Bu}$ da gösteriyor ki Hz. Peygamber hilyelerinin beyit sayısı diğer hilyelerin beyit sayısının yaklaşık 5 katıdır. Eser sayısı itibariyle de Hz. Peygamber hilyeleri diğer hilyelerin yaklaşık iki katıdır.

Sonuç olarak diyebiliriz ki müstakil hilyelerde büyük oranda mesnevi nazım şekli kullanılmış, hacimli olmayan ve daha çok müstakil bir eser içerisinde bir bölüm olarak yazılmış hilyeler ise çoğunlukla kaside şeklinde yazılmıştır. Mesnevi nazım şekliyle yazılan hilyelerde zaman zaman farklı nazım şekillerine de yer verilmiştir. Beyit sayıs1 6 ile 4071 arasında olan toplam 43 hilyede en çok tercih edilen aruz kalıbı Hâkânî’nin hilyesinde kullandığı kalıp olan "Fe'ilâtün Fe'ilâtün Fe'ilün”dür. Bununla birlikte Âşık Kadrî, hilyesinin bir bölümünü aruzla bir bölümünü heceyle, Hayreddin Karaman ise manzumesinin tamamını hece vezniyle yazmıştır.

\section{Yeni Manzum Hilye Metinleri}

İlgili kütüphane kayıtlarında hilye adıyla kaydedilmesinerağmen Merâmî ile Halepli ‘Îdî’ nin hilyeleri, hilye ile ilgili çalışmalarda adından bahsedilmeyen şairlerdir. Her ne kadar bu hilyelerin edebî değeri yüksek olmasa da söz konusu bu manzumler, şimdiye kadar adı hep hilye sahasında anılmış olan Selîmî Dede'nin manzumesinden çok daha fazla hilye özelliği göstermektedir.

Merâmî ve ‘İdî’nin yanı sıra müstakil bazı eserler içerisinde yer alan hilyeler de ilgili çalışmalarda adından bahsedilmeyen manzumelerdir. Çok sayıda eseri özellikle de basılmış ya da tez olarak hazırlanıp basılmamış pek çok divanı incelememiz sonucunda birkaç hilyeye rastladık. Selâmî Divanı, Abdullah Ferdî Divanı ile İsmâil Sâdık Kemâl Paşa'nın Âsâr-ı Kemâl adlı eserinde Hz. Peygamber hilyesi bulunmaktadır. Ayrıca Râzî Divanı'nda 66 beyitlik bir Hacı Bayram-1 Velî hilyesi yer almaktadır. Hûdek-zâde Nu'mân Vehbî Efendi, Manzume-i Nu 'mâniyye adlı mesnevi nazım şekliyle yazılmış eserinde 27 beyitlik kasidesi bir peygamberler hilyesidir.

Bunların dışında aşağıda haklarında bilgi verilen üç hilye, yine konu ile ilgili kaynaklarda adı anılmayan manzum hilyelerdir. 
Hayreddin Karaman'ınGönüllerinSüsü, Hanelerin Zineti Hilye Peygamberimizin Şekil ve Şemâili adlı eserinin başında her bendi altı mısradan oluşan 17 bentlik bir manzume bulunmaktadır. 1992 yılında kaleme alınan ve 11'li hece ölçüsüyle yazılan bu manzumenin ilk 9 bendinin her birinde Hz. Peygamber'in bir uzvu anlatılmıştır. Her bendin sonunda yer alıp nakarat gibi kullanılan iki beyitte manzumenin sonuna kadar Hz. Peygamber'i görme arzusu dile getirilmiştir.

Yine Hayreddin Karaman'ın 2008 y1lında bas1lanGönüllerin Süsü Hanelerin Zineti Hilye adlı eseriHâkânî'nin hilyesinin 713 beyitlik manzum tercümesidir. 14'lü hece ölçüsüyle yazılmıştır. Sayfanın bir tarafında Hayreddin Karaman'ın tercümesi, diğer tarafta ise Hâkânî’nin hilyesi bulunmaktadır.

Seyrî mahlasını kullananYüzakı Dergisi Genel Yayın Yönetmeni Muhammet Ali Eşmeli tarafından 2009 yılında tamamlanıp 2011 yılında basılan Hilye-i Şerîfe adlı eser, aruzun Fe'ilâtün Fe'ilâtün Fe'ilün kalıbıyla ve mesnevi nazım şekliyle yazılmış olup 1001 beyitten oluşmaktadır. Eşmeli, eserin hemen başında yer alan Lutf-1 Hudâ başlıklı bölümde daha önceden bazı beyitler yazmasına rağmen Hilye-i Şerîfe' yi bir türlü tamamlayamadığını, 2009 yılında ağır bir şekilde hastalanmasının üzerine içinde hilye yazmaya yönelik kuvvetli bir aşk kıvılcımı parladığını ve eserini 13 gün gibi kısa bir sürede tamamlayabildiğini ifade etmektedir. ${ }^{9}$

\section{Hilye Benzeri Manzumeler}

SeyyidNesîmî Divânı ile Dede Ömer Rûşenî Divanı'nda çok sayıda tuyuğ ${ }^{10}$ bulunmaktadır. Bu tuyuğların bir kısmında divan şiirinin klasik benzetmeleri ile $\mathrm{Hz}$. Peygamber'in kaşları, gözleri, kirpikleri, ağzı, dişleri, boynu, boyu ve peygamberlik mührünün övgüleri yapılmıştır. Hz. Peygamber'in ya da diğer kişilerin uzuvlarının değişik benzetmelerle yapılan övgüsüne aslında bütün hilyelerde rastlanmaktadır. Bu durum bütün hilyelerin ortak özelliğidir. Bunun dışında klasik bir hilyede ele alınan kişiyle ilgili gerçekçi bilgilere de yer verilir ki bir hilyeyi hilye yapan asıl unsurun da bu olduğunu düşünüyoruz; çünkü gerçeğe dayanan bu bilgiler sayesinde hilyesi yazılan kişinin fiziksel portresi çizilebilmektedir. Seyyid Nesîmî Divanıile Dede Ömer Rûşenî Divanı'nda yer alan bu tuyuğlarda Hz. Peygamber'in portresi yalnızca bazı benzetmelere dayalı olarak verildiğinden bunları "hilye benzeri manzumeler" olarak değerlendiriyoruz.

9 Eşmeli, Muhammet Ali (Seyrî). Hilye-i Şerîfe, İstanbul: Yüzak1 Yayıncılık, 2010, 24.

10 Arap ve İran edebiyatında görülmeyen, yalnız Türk edebiyatında kullanılan dört mısralık bir nazım şeklidir. Halk edebiyatındaki maninin, divan edebiyatındaki rubainin karşılığı olarak kabul edilir. 
Bülent Şiğva, Seyyid Nesîmî’nin tuyuğları üzerine yazdığı bir makalesinde Seyyid Nesîmî'nin tuyuğlarını yalnızca Hâkânî’nin hilyesisiyle karşılaştırarak şöyle demektedir: Tuyuğlarda hilye metinlerinde gördüğ̈̈müz anlatımlara uygun bir anlatım sergilediğinin ortaya konulması, Nesîmî’nin tuyuğlarının hilye özelliği gösterdiği dü̈süncesini desteklemiştir. ${ }^{11}$ Bir başka yerde ise Nesîmî'nin Divanı 'nda 315 adet tuyuğ bulunmaktadır. Bunlart tasnif ettiğimizde 104 adet tuyuğun hilye özelliği taşıdı̆̆ını görmekteyiz. Hilye özelliği taşıyan tuyuğlara bakıldığında tasvirden çok uzuvların övgüsünün yapıldiğı görülmektedir ${ }^{12}$, şeklinde ifadelere yer vermiştir. Yukarıda da belirttiğimiz gibi bu tuyuğlardaki anlatım, diğer bir ifadeyle tasvir yöntemi hilyelere kısmen uymaktadır. Kendisinin de dediği gibi bu tuyuğlarda tasvirden çok övgü vardır. Dolayısıyla kendisinin bu tuyuğların tam olarak hilye olduğu yönündeki düşüncesine katılmadığımızı belirtmek isteriz.

İsmail Yıldırım tarafından kaleme alınan bir başka yazıda XVII. yüzyıl şairlerinden Azîz Mahmûd Urmevî’nin Tezkire-i Hazret-i Baba adlı eserinde Hz. Peygamber hilyesinin bulunduğu şöyle ifade edilmektedir: Şairin, eserde söz konusu mahlasla kaleme aldiğı 18. ve 19. hikâyeler muhteva itibariyle hilye niteliği taşımaktadır. Şairin kaleme aldiğı hilyeler, şeklen kusurlu olsa da içerik bakımından Nebî'nin vasıflarını beyan eden, okunmaya değer hilyelerdir. ${ }^{13}$ Bizce 18 . Hikâye hilye değil, kısmen belki hilye benzeri manzume olarak kabul edilebilir. 19. Hikâyenin ise hilye ile uzaktan ya da yakından bir ilgisi bulunmamaktadır.

\section{Manzum Hilyelerle İlgili Tekrarlanan Bazı Yanlışlar}

Hilyeler üzerine yapılan hemen hemen bütün çalışmalarda sürekli tekrarlanan bazı yanlış bilgilere yer verilmektedir. Bunları maddeler hâlinde aşağıda sıralamak istiyoruz.

1. Kastamonulu Nûrî, Azîz Mahmûd Hüdâyî ve Merâmî'nin Hilyesi Var mı?: Kastamonulu Nûrî, Azîz Mahmud Hüdâyî ve Merâmî adına kayıtlı hilye nüshalarının hepsi Şerîfî' nin hilyesinin bir bölümünü içeren nüshalardır. Nûrî ve Azîz Mahmûd Hüdâyî’nin hilyesi yoktur. En azından Azîz Mahmûd Hüdâyî adına kayıtlı nüshanın ona ait olmadığını söyleyebiliriz. Merâmî’nin ise altı beyitlik küçük bir hilyesi vardır.

2. Cûdî’nin Hilyesi Var mı?: Her ne kadar kütüphane kayıtlarında Cûdî mahlaslı bir şaire ait hilyenin varllğından bahsedilse de bu hilyelerin tamamı Cevrî̀ye aittir.

11 Şığva, Bülent. “Nesîmî’nin Tuyuğları Hilye Midir?”, Erzincan Üniversitesi Sosyal Bilimler Enstitüsü Dergisi, ÖS-III (2016): 169-192.

12 Şığva, Bülent.agm.,173.

13 Yıldırım, İsmail. "Urmevî’nin Tezkire-i Hazret-i Baba Adlı Eserinde Hilye-i Şerîf Bölümü”, Uluslararası Türkçe Edebiyat Kültür Eğitim Dergisi, 3/4 (2014): 75-94. 
Cûdî ve Cevrî kelimelerinin Araplı harfli yazımındaki benzerlik, Cevrî kelimesinin yanlışlıkla Cûdî olarak okunmasına neden olmuştur.

3. Niyâzî-i Mısrî’nin Hilyesi Var mı?: 2002 yılında Niğde Üniversitesi’nde tek nüshaya dayanılarak Niyazi-yi Mısrî'nin Hilye-i Şerîf Adlı Eseri Üzerine Bir Çalışma (İnceleme-Metin-Sözlük) başlıklı bir tez hazırlanmıştır. Bu tezde ortaya konulan metin Niyâzî-i Mısrî’ye değil, Nüvâzî’ye aittir. Zaten metin içerisinde altı yerde Nüvâzî, mahlasını açıkça kullanmıştır. Nüshanın ilk sayfasında yer alan Tercüme-i Hilye-i Şerîf-i Nüvâzî” başlığında geçen Nüvâzî kelimesinin yanlışlıkla Niyâzî olarak okunması bu karışıklığa neden olmuştur.

4. Nakşî Mustafa Dede'nin Hilyesi Var mı?: Nakşî Mustafa Dede'ye ait bir hilye yoktur. Nakşî Mustafa Dede adına kayıtlı bütün hilyeler aslında Lütfî Çelebi'nin hilyesinin yalnızca bir bölümüdür. Lütfî Çelebi'nin hilyesinde bir beyitte geçen "nakşının” kelimesinin mahlas zannedilerek "Nakşî’nin” şeklinde okunması, Lütfî Çelebi’nin hilyesinin farklı bir hilye olarak algılanmasına neden olmuştur.

5. Hayrullah Hayrî’nin Hilyesi Var mı?: Millî Kütüphane No: 06 Yz A 158/2'de 31a- 35b varakları arasında Hayrî adına kayıtlı 94 beyitlik bir hilye yer almaktadır. $\mathrm{Bu}$ manzumenin Hayrî mahlaslı bir şaire ait olduğu sonucu aşağıdaki şu beyitten çıkarılmış olmalıdır. Nitekim manzumenin bilinen tek yazma nüshasında "hayrı" kelimesinin altı çizilmiştir.

Yeter ey hâme-i şîrîn-güftâr

Eylegil hâtime-i hayrı karâr

"hayrı" kelimesinin "Hayrî" şeklinde okunması ve manzumenin kütüphane kayıtlarında Hayrullah Hayrî adına kaydedilmiş olması bu hilyenin Hayrullah Hayrî'ye ait olduğu düşüncesini ortaya çıkarmıştır. Yukarıdaki beyitte geçen "hâtime-i hayrı" ifadesi "hâtime-i Hayrî" şeklinde de okunabilir. Daha anlamlı olduğunu düşündüğümüz için biz ilk şekli tercih ettik. Ayrıca hilye içerisinde geçen bir beyitten manzumenin 1111/1699 yılında tamamlandığını anlamaktayız. O dönemde yaşayan Hayrî mahlaslı iki şair vardır. Ancak kaynaklarda bu iki şaire ait Hilye-i Şerîf adıyla kayıtlı bir eser görünmemektedir. Elimizde sağlam bir delil olmadığı için söz konusu bu manzumeyi şimdilik, "Müellifi Bilinmeyen Hilye" adıyla anmanın daha uygun olacağını düşünüyoruz. ${ }^{14}$

14 Sadık Beklen ve Hasan Şener tarafından hazırlanan bir makalede Hayrullah Hayrî’ye ait olup olmayacağı tartışmasına yer verilmeden söz konusu hilye, “Türk Edebiyatında Hilye ve Hayrî’nin Hilye-i Şerîfi” adıyla yayımlanmıştır. bk. Sadık Beklen, Hasan Şener:"Türk Edebiyatında Hilye ve Hayrî’nin Hilye-i Şerîfi”, Külliyat Osmanlı Araştırmaları Dergisi, 1 (2017),1-14. 
6. Hz. Hatice'nin Tasvir Edildiği Bir Hilye Var mı?: 2017 yılında Fatih Köse tarafindan "Hilye Geleneğine Bir Katkı: Eski Anadolu Türkçesi Dönemine Ait İki Mesnevide Hz. Hatice (r.a.) Tasvirleri” adlı bir makale yayımlanmıştır. Bu makalede yazarı bilinmeyen bir Hz. Hatice siyeri ile Gulâmî'nin Dâsitân-ı Hadicetü'l-Kübrâ adlı mevlinden hareketle Hz. Hatice ile ilgili bazı hususlar ele alınmıştır. Yazarın ifadesiyle söz konusu makale $\mathrm{Hz}$. Hatice'nin fiziki, karakteristik ve maddi özelliklerini içeren bölümlerden oluşmaktadır. ${ }^{15}$ Ancak makalenin devamında Gulâmî'nin eserinde fiziki tasvirler hiçbir şekilde yer almazken diğer eserde tüm divan edebiyatında tasvir edilen ideal kadına ait unsurların Hz. Hatice' ye yüklenmiş olduğu görülmektedir ${ }^{16}$, denildikten sonra Hz. Hatice'nin yüzü, gözleri, saçı, dişleri, yanağı ve boyuyla ilgili eserde geçen birkaç beyite yer verilmiştir. Bu beyitlerde Hz. Hatice'nin yüzünün nurlu, gözlerinin nergis, saçının reyhan, dudaklarının lal, dişlerinin inci gibi olduğu ifade edilmiştir ve yazar buradan hareketle bu beyitlerin hilye olduğu kanısına varmıştır. Makaleye "Hilye Geleneğine Bir Katkı" adını vermesine rağmen makale içerisinde bir kez olsun hilye kelimesini kullanmadığı gibi kaynakça bölümünde de hilyeyle doğrudan ilgili tek bir kaynağa da yer vermemiştir. Dolayısıyla söz konusu makalenin Hz. Hatice hilyesini konu edinmediği açıkça ortadadır.

7. Gülistân-ı Şemâil Kimin?: Hz. Muhammed hilyesi olan Gülistân-ı Şemâ' 'il kaynaklarda Mehmed Nesîmî adına kayıtlıdır. Eserde Mehmed adının bulunmasına rağmen Nesîmî adı geçmemektedir. ${ }^{17}$ Sadece bu bilgiden hareketle eserin müellifini tespit etmek imkânsız görünmektedir. Zaten kaynaklarda Mehmed Nesîmî adlı bir şairle ilgili bilgi de bulunmamaktadır.

Gülistân-l Şemâi ${ }^{18}$, ünlü şeyhülislam ve tarihçi Hoca Sadeddîn Efendi'nin küçük oğlu Hocazade lakabıyla tanınan Mehmed Es'ad Efendi’ye aittir. Mehmed Es'ad Efendi adına yine Gülistân-ı Şemâ'il adıyla kayıtlı dört halife hilyesi bu bilgiye ulaşılmasını sağlamıştır. Dört halife hilyesinin sonunda Mehmed Es 'ad Efendi'nin künyesi bulunmakta olup bu hilyede Mehmed Es'ad Efendi daha önceden Gülistân-l Şemâ'il adında bir Hz. Muhammed hilyesini yazdığını açıkça ifade etmiştir.

15 Köse, Fatih, "Hilye Geleneğine Bir Katkı: Eski Anadolu Türkçesi Dönemine Ait İki Mesnevide Hz. Hatice (r.a.) Tasvirleri”, Gazi Üniversitesi Sosyal Bilimler Dergisi, C.4, S.11 (2017): 473.

16 Köse, Fatih, a.g.m., s. 485.

17 Bu eser üzerine Zülfikar Güngör doktora tezi hazırlamıştır. bk. Güngör, Zülfikar, Türk Edebiyatında Türkçe Manzum Hilye-i Nebevîler ve Nesîmî Mehmed'inGülistân-1 Şemâil'i, Yayımlanmamış Doktora Tezi, Ankara: Ankara Üniversitesi Sosyal Bilimler Enstitüsü, 2000.

18 Mehmed Es‘ad Efendi'nin Gülistân-1 Şemâil’i ile babası Hoca Sa'deddîn Efendi'nin Hilye-i Celiyye ve Şemâ'il-i 'Aliyye adlı mensur hilyesi arasındaki benzerlikler için bk. Mehtap Erdoğan Taş:“Hoca Sa ‘deddîn Efendi’nin Mensur Hilyesi: Hilye-i Celiyye ve Şemâ'il-i ‘Aliyye”, Amasya Üniversitesi Fen-Edebiyat Fakültesi Sosyal Bilimler Dergisi, C.2, S.3 (2018),19-60. 
8. Gülistân-ı Şemâil mi Çâr-Bâ̆g mı?: Mehmed Es'ad Efendi edebiyatımızda iki müstakil hilye yazan tek isimdir. Hilyelerinden biri Hz. Muhammed hilyesi, diğeri ise dört halife hilyesi olup her ikisi de Gülistân-ı Şemâil adıyla anılmaktadır. Mehmed Es'ad Efendi, Hz. Peygamber hilyesi olan eserine Gülistân-ı Şemâil adını verdiğini aynı eserde birkaç beyitte açıkça belirttiği gibi dört halife hilyesinde de bu konuya değinmiş, daha önceden yazmış olduğu Hz. Muhammed hilyesine bu adı verdiğini söylemiştir. Ancak Es'ad Efendi'nin dört halife hilyesinde yapmış olduğu bu açıklama yanlış anlaşılmış olacak ki bugüne kadar dört halife hilyesi de bazı çalışmalarda hep Gülistân-ı Şemâil adıyla anılmıştır. Her ne kadar Mehmed Es'ad Efendi, Hz. Muhammed hilyesine Gülistân-ı Şemâil adını verdiğini belirttiği kadar açıkça belirtmemiş olsa da bir beyitte dört halife hilyesi için "adına Çâr-bâğ denilse uygundur" ifadesini kullanmıştır. Biz de bu bilgilerden hareketle ve her iki eserin aynı adda olmasından kaynalanacak bir karışıklığa meydan verilmemesi için eserin Çâr-bâğ olarak anılmasının daha uygun olacağını düşünüyoruz.

9. Tek Peygamberler Hilyesi Sahibi Neşâtî mi?:Bugüne kadar ilgili bütün kaynaklarda Neşâtî'nin Hilye-i Enbiyâ 'sı tek manzum peygamberler hilyesi olarak anılmıştır. Oysaki Hûdek-zâde Nu'mân Vehbî Efendi'nin Manzûme-i Nu 'mâniyye içinde yer alan 27 beyitlik peygamberler hilyesi müstakil olmamakla birlikte ikinci manzum peygamberler hilyesi olarak hilye literatüründe yer almalıdır.Hûdek-zâde Nu'mân Vehbî Efendi, 1276/1860 yılında Trabzon'un Of ilçesinde doğmuş olan ve 1338/1922'de Of müftüsü iken 62 yaşında vefat etmiştir.Manzume-i Nu 'mâniyye adlı mesnevi nazım şekliyle yazılmış eserindeki 27 beyitlik kasidesi bir peygamberler hilyesidir. Bu kasidede Hz. Âdem, Hz. Nuh, Hz. Musa, Hz. Harun, Hz. Lut, Hz. Yakub, Hz. Yusuf, Hz. Davud, Hz. İsa, Hz. Muhammed, Hz. İbrahim ve Hz. İsmail olmak üzere 12 peygamber peygamberin hilyesi birkaç beyitle verilmiştir. ${ }^{19}$

10. Son Hilye Sahibi Kim?: Mustafa Fehmi Gerçeker'in 1944 yılında basılan Hilye-i Fahr-i Âlem adlı eseri bugüne kadar hep son hilye örneği olarak gösterilmiştir. Ancak bu eserden sonra yukarıda da bahsedildiği üzere üç tane daha manzum hilye yazılmıştır. Bu sebeple yeni bir örneği yazılıncaya dek şimdilik son manzum hilye sahibi, Seyrî mahlasını kullanan Muhammet Ali Eşmeli olarak kabul edilmelidir.

\section{Hilye Adıyla Anılmasına Rağmen Hilye Özelliği Göstermeyen} Manzumeler Hangileri?:Hilye adı gerek Türk edebiyatında gerekse Arap ya da Fars edebiyatlarında her zaman yalnızca edebî bir türün adı olmamış zaman zaman farklı içerikli eserlere de hilye adı verilmiştir. Örneğin,

19 Hilyetü'l-Enbiyâ'nın tam metni ve muhteva özellikleri için bk. Erdoğan, Mehtap,age.,715-716. Ayrıca yazar ve eseri hakkında ayrıntılı bilgi için bk. Mehmet Emin Ertan:Hûdek-zâde Nu'mân Vehbî Efendi, Manzûme-i Nu'mâniyye, Ankara: Kurtuba Yayınları,2012. 
- Hilyetü'l-İnsân ve Helbetü'l-Lisân, Cemâleddîn İbn Mühennâ.

- Hilyetü'r-Ricâl, Gelibolulu Mustafa Ali.

- Hilye-i Sâdât, Mustafa Fevzî bin Nu'mân.

- Hilyetü'l-Efkâr, Nev'î-zâde Atâyî.

- Hilyetü'l-Evliyâ ve Tabakatü'l-Asfiyâ, Ebu Nuaym El-Isfâhânî.

- Hilyetü'l-Abdal, Muhyiddîn İbnü'l-Arabî.

- Hilyetü ehli'l-Kemâl, Ebûbekr Receb b. İsmail Eş-Şenevânî.

- Hilyetü Ehli’l-Fazl, Aclûnî.

Bu eserler; bazı mümtaz şahsiyetlerin, sûfîlerin, zâhidlerin, âbidlerin, rical-i gayb zümresinin, hadisçilerin, sahabeden ve evliyalardan bazılarının hayatlarının, örnek alınacak ibret dolu sözleri ile davranış biçimlerinin gözler önüne serildiği, menkıbelerinin, biyografilerinin büyük ölçüde kronolojik sırayla ele alındığı türde eserlerdir. Bununla birlikte hilye adı verilen bir tane sözlük (Hilyetü'l-ínsân ve Helbetü'l-Lisân, Cemâleddîn İbn Mühennâ) ve bir tane de dilbilgisi kitabı (Hilyetü ehli'l-Kemâl, Ebûbekr Receb b. İsmail Eş-Şenevânî) bulunmaktadır. Yukarıda adı geçen Hilye-i Sâdât ise 33 bölümden oluşan bir silsilename olup her bölümün sonunda bahsi geçen şahsın birkaç beyitle hilyesine yer verilmiştir. Hilye-i Sâdât üzerine çalışan Ferdi Kiremitçi 2871 beyiti mesnevi,113 beyti başka nazım şekilleriyle yazılmış 2984 beyitlik eserde toplam 264 beyitin hilye özelliği taşıdığını söyler (2017: 149). Yani hilye olarak yazılmış beyitler eser içerisinde oldukça azdır. Bu nedenle Mustafa Fevzî b. Nu'mân'a ait olan Hilye-i Sâdâtda doğrudan hilye türünde yazılmış bir eser değil, bir silsilenamedir. Sonuç olarak hilye adı taşıyan her eserin edebî bir tür olan hilye ile karıştırılmaması gerektiği söylenebilir.

\section{SONUÇ}

Bu çalışmada hilyenin kapsamlı bir tanımı yapılmış, edebî bir tür olarak hilyelerin ortaya çıkışına ve kaynaklarına dair bilgiler verilmiştir.Söz konusu tür, nazire ve zeyl kavramları etrafında ele alınarak muhteva ve şekil özellikleri yönünden değerlendirilmiştir. Ayrıca tarafımızca tespit edilen yeni hilye metinlerinden bahsedilerek hilyelerdeki tasvir yöntemlerinden hareketle bazı metinlerin hilye değil, hilye benzeri manzumeler olarak kabul edilebileceği ifade edilmiştir. Tespit ettiğimiz bütün manzum hilye metinleriniinceleyerekelde ettiğimizveriler, bugüne kadar pek çok çalışmada tekrarlanan yanlışları düzeltecek şekilde ortaya konmuştur. Aslında elinizdeki makalede yer alan bilgiler uzun ve yoğun bir çalışma neticesinde elde edilen sonuçlardır. Bu bilgilerin bundan sonra manzum hilyeler üzerine 
kaleme alınacak diğer çalışmalara kaynaklık etmesi hem yeni bilgilerin ortaya konmasıhem de konuyla ilgili bilinen yanlışların düzeltilmesi bakımındanbüyük fayda sağlayacaktır.

Hakem Değerlendirmesi: Dış bağımsız.

Çıkar Çatışması: Yazar çıkar çatışması bildirmemiştir.

Finansal Destek: Yazar bu çalışma için finansal destek almadığını beyan etmiştir.

Peer-review: Externally peer-reviewed.

Conflict of Interest: The author has no conflict of interest to declare.

Grant Support: The author declared that this study has received no grant support.

\section{Kaynakça/References}

Ayan, Hüseyin. Nesîmî Hayatı, Edebî Kişiliği, Eserleri ve Türkçe Divanının Tenkitli Metni, C. 2, Ankara: TDK Yayınları, 2002.

Beklen, Sadık, Şener Hasan. “Türk Edebiyatında Hilye ve Hayrî’nin Hilye-i Şerîfi”. Külliyat Osmanlı Araştırmaları Dergisi, S. 1 (2017): 1-14.

Erdoğan Taş, Mehtap. “Hoca Sa'deddîn Efendi'nin Mensur Hilyesi: Hilye-i Celiyye ve Şemâ'il-i ‘Aliyye”. Amasya Üniversitesi Fen-Edebiyat Fakültesi Sosyal Bilimler Dergisi, C.2, S.3 (2018): $19-60$

Erdoğan, Mehtap. Türk Edebiyatında Manzum Hilyeler. İstanbul: Kitabevi Yayınları, 2013.

Ertan, Mehmet Emin.Hûdek-zâde Nu'mân Vehbî Efendi,Manzûme-i Nu'mâniyye. Ankara: Kurtuba Yayınları, 2012.

Eşmeli, Muhammet Ali (Seyrî). Hilye-i Şerîfe. İstanbul: Yüzakı Yayıncılık, 2010.

Güngör, Zülfikar, Türk Edebiyatında Türkçe Manzum Hilye-i Nebevîler ve Nesîmî Mehmed'inGülistân-1 Şemâil'i, Yayımlanmamış Doktora Tezi. Ankara: Ankara Üniversitesi Sosyal Bilimler Enstitüsü, 2000.

Güngör, Zülfikar. “Türk Edebiyatında Hilye-i Nebevî Türünün Doğuşu Gelişimi ve Sebepleri”. İlmî ve Akademik Araştırma DergisiTasavvuf, S. 10 (2003): 185-199.

Karaman, Hayreddin. Gönüllerin Süsü Hanelerin Zineti Hilye. İstanbul: Ufuk Kitapları, 2008.

Kiremitçi, Ferdi. Mustafa Fevzî B. Nu'mân Hilye-i Sâdât (Nakş-Bendî Silsilesinin Manzum Menâkıb ve Şemâili). İstanbul: Kesit Yayınları, 2017.

Köse, Fatih. "Hilye Geleneğine Bir Katkı: Eski Anadolu Türkçesi Dönemine Ait İki Mesnevide Hz. Hatice (r.a.) Tasvirleri”. Gazi Üniversitesi Sosyal Bilimler Dergisi, C.4, S.11 (2017): 473-495.

Sağır, İdris. Kur'an'da Zinet Kavramı, (Basılmamış Yüksek Lisans Tezi). Kahramanmaraş: Kahramanmaraş Sütçü İmamÜniversitesi Sosyal Bilimler Enstitüsü, 2009.

Soydan, Serpil. Niyazi-yi Mısrî’nin Hilye-i Şerîf Adlı Eseri Üzerine Bir Çalışma (İnceleme-Metin-Sözlük), Yayımlanmamış Yüksek Lisans Tezi. Niğde: Niğde Üniversitesi Sosyal Bilimler Enstitüsü, 2002.

Şığva, Bülent. “Nesîmî’nin Tuyuğları Hilye Midir?”. Erzincan Üniversitesi Sosyal Bilimler Enstitüsü Dergisi, ÖS-III (2016): 169-192. 
Tavukçu, Orhan Kemal. Dede Ömer Rûşenî, Hayatı, Eserleri, Edebî Kişiliği ve Divanının Tenkitti Metni. Erzurum: Suna Yayınları, 2005.

Türk Dili ve Edebiyatı Ansiklopedisi 1981: 237.

Yardım, Ali. Peygamberimizin Şemâili. İstanbul: Damla Yayınevi, 2011.

Yıldırım, İsmail.“Urmevî’nin Tezkire-i Hazret-i Baba Adlı Eserinde Hilye-i Şerîf Bölümü”. Uluslararası Türkçe Edebiyat Kültür Eğitim Dergisi, 3/4 (2014): 75-94. 
